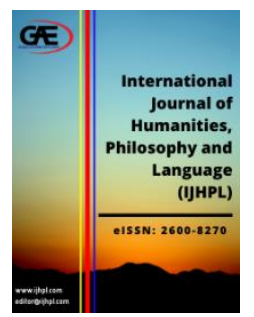

International Journal of Humanities, Philosophy and Language (IJHPL)

\title{
A REVIEW OF INFLUENCE FROM FIRST AND SECOND LANGUAGE AS SYNTAX INTERFERENCE IN THE GERMAN LANGUAGE
}

\author{
Robe'ah Yusuf ${ }^{1}$, Mariyati Mohd Nor ${ }^{2}$, Zarima Mohd Zakaria ${ }^{3}$, Norjietta@ Julita Taisin ${ }^{4}$ \\ $1 \quad$ Universiti Pendidikan Sultan Idris. \\ Email: robe_ah@pbmpu.upsi.edu.my \\ 2 Universiti Pendidikan Sultan Idris. \\ Email: mariyati@pbmpu.upsi.edu.my \\ 3 Universiti Pendidikan Sultan Idris. \\ Email: zarima@fbk.upsi.edu.my \\ $4 \quad$ Universiti Pendidikan Sultan Idris. \\ Email: norjieta@fbk.upsi.edu.my
}

\section{Article Info:}

\section{Article history:}

Received date: 13.11.2019

Revised date: 24.11 .2019

Accepted date: 22.04.2020

Published date: 10.06.2020

\section{To cite this document:}

Yusuf, R., Nor, M. N., Zakaria, Z. M., \& Taisin, N. J. (2020). A Review of Influence from First and Second Language as Syntax Interference in The German Language. International Journal of Humanities, Philosophy and Language, 3 (10), 18-44.

DOI: $10.35631 /$ IJHPL.310004.

\begin{abstract}
:
The syntax is the field of studies in constructing sentences which is the knowledge in a language that studies the form, structure, and sentence construction. In general, syntax is involving the system that studies the rule and categories in the foundation of constructing sentences for a language. The syntax is not only research on the process of constructing sentences but also including the laws that determine how the words arranged in the sentences. Thus, the objective of this article is to study the literature review on constructing sentences in the German language that influenced by the first and second languages. Some of the researchers find that the first and second language is named by syntax interference. Based on the qualitative methodology, this article recorded seven articles from the years 2015 until 2020. The research on syntax which focusing on the German language is needed because this language is one of the subjects learned in selected schools and universities in Malaysia. Hence, it is hoped that this paper can enlighten other researchers on the German language syntax.
\end{abstract}

Keywords:

Constructing Sentences, Primitives, Searched, Keywords

\section{Introduction}

The syntax is about the law or grammatical formula based on the methods of combination and arrangement of words or words cluster to form the sentences in certain languages. This study Copyright $\odot$ GLOBAL ACADEMIC EXCELLENCE (M) SDN BHD - All rights reserved 
is look up to the forms, structures and sentences construction with the law or grammatical formula on how to combine the sentences. Other than that, the study on syntax is also involving the aspect of difference in constructing the sentences through the types and variations of sentences. According to Kaiser, Peyer dan Berthele (2014), a syntax is related to the word of sentence construction which comprises an object, subject, and predicate (SVO). However, as for the researchers in Malay language studies, the syntax is referred to as the field that studies the systematic rule in classifying each category as the basic in constructing the sentences for certain languages (Maslida, 2006). From the past literature review, it is found that sentence construction is the biggest challenge for language students. As for the German language, the constructed sentences must contain the conjugation law and mostly the students are making mistakes for that.

(Robe'ah, 2010; Aida Husni, 2012). According to Rowinah (2012), usually, the students are having difficulty in constructing the sentences in the German language because the grammatical law is in as many details which the students will choose various learning patterns to master the German language. Most of past researchers found that the first and second language are influencing the construction of sentences in German language (Haslina, 2016). Some researchers found that the evidence on the construction of the sentences which is influenced by the first and second language which namely as syntax interferences (Agus\&Muhammad Zaki, 2018). The first and second languages have already existed in language students cognitively which is the German language. Thus, the construction of sentences in the German language will be influence by the dominant language. The acquired language or learned earlier will become the primary reference in students' minds (Obodoeze \& Ugagu-Dominic, 2018). The researchers find that this issue is important to be researched however the past research on this area is least implemented in Malaysia.

\section{Research Methodology}

This research is utilizing the method of a review of literature in which the purpose is to handle this issue by identifying, critical evaluation and integrating the research discovery. (Baumeister \& Leary, 1997; Bem, 1995; Cooper, 2003). The justification of this methodology is because it is suitable and relevant to evaluate systematically as a whole to the research that related to the German language from many years and filling the void or gap on the research. This method will apply the step by step searches to identify the German language syntax, influences of the first and second language and interferences. The research methodology is the documented analysis of the books, journals, and thesis written by scholars. The reference is ranging from the year 1998 to 2020. This is because, the German language only offers as a degree (Bachelor's Degree) in Malaysia during the year 1998 at the University of Malaya (Robe'ah, 2010). However, the researcher lists the topic and research works from 2015 onwards until 2020 because the discussion about the German language syntax is only discussed and researched around that year which refers to the finding of the studies in Table 1. which is the review on this topic. The latest literature review and relevant are from the recent five years as suggested by many Higher Education Institutions in Malaysia. The research objectives are :

i) To identify the scholar's intellectual opinion regarding the syntax's issues in the German language.

ii) To analyse the need to study foreign languages specifically German language based on the gap in past researches.

The past researches collected through the phrases or keywords which are related to "German language syntax" and "interferences". The purpose is the researches excluding the topic of 
German language studies such as morphology and semantics will elicit from the system of literature review. The researcher also will elicit any researches related to the translation of the German language through the keywords of "German language syntax" and "interferences". The researcher also will search for the English and German language translation from both of the keywords. The earlier search is named as primitive search (Cooper, 2003). As following are the sums of the articles found in this research. Diagram 1. Explains how the process of researching the titles, abstract and table of contents from past researches.

\section{Diagram 1: The Primitive Phrases And Keywords Search}

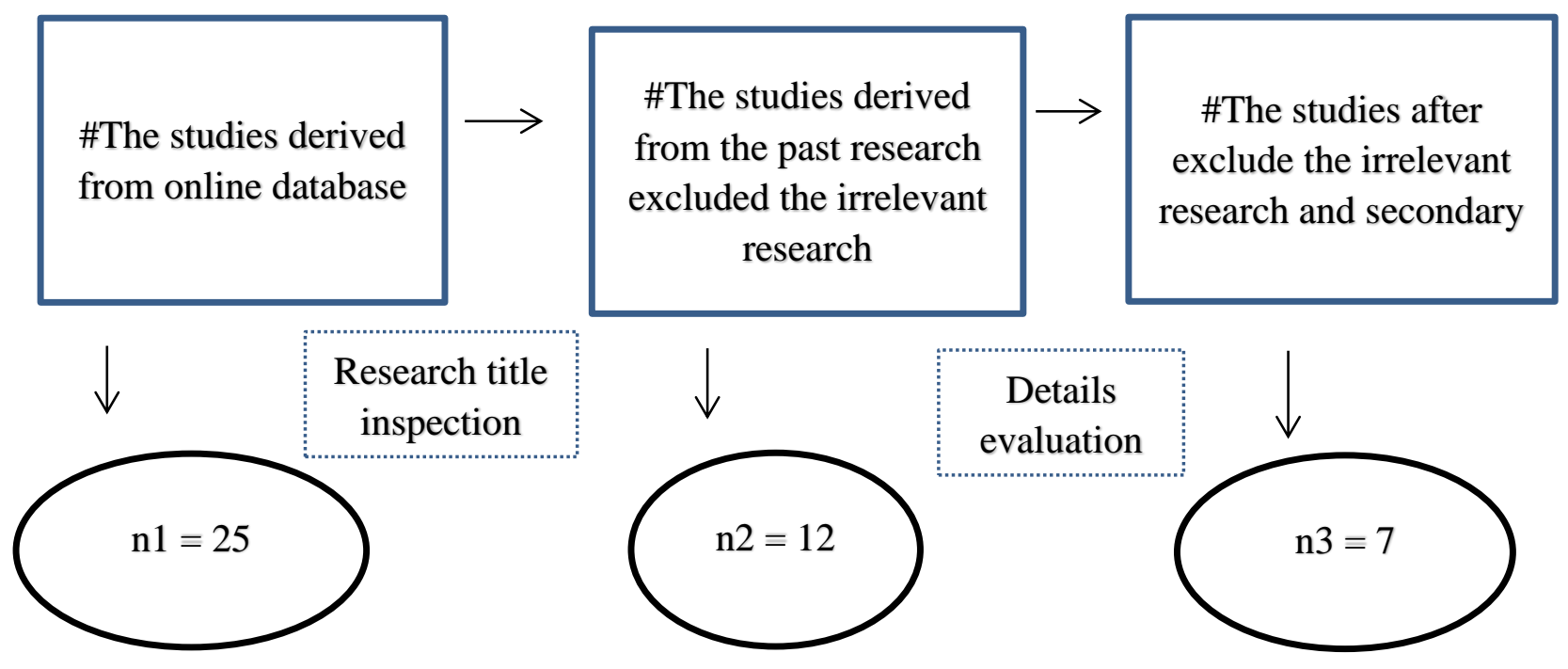

Adapted from Cooper, H. M. (2003). Editorial. Psychological Bulletin.

Diagram 1. shows that this research is using the analytical literature review that includes the research's year, the background of the research, issue, methodology, and findings of studies that refers to the literature review. This method is implementing the procedure searches to identify the research on "German language syntax". The matrix principle of the literature review has also been implemented by many other researchers recently as an opening to the phenomenon of research keywords (Michie \& Williams, 2003; Dewey \& Drahota, 2019). In this research, the keywords of "German language syntax" and "Interference" has been used to obtain the research data. This research also assists with the access of databases from Google, Researchgate and Academia. From the 25 searches of the documents of articles journals that related to this research, there are only seven articles that are accepted to be analysed, and the search scope is from the year 2015 until 2020 with the research title that is similar to the researcher studies.

\section{Findings of Studies and Discussion}

The first findings of the studies are obtained through the keywords of "interferences" which indirectly refers to the involvement of foreign language issue and the influence of first and second language. Thus, it will make it easier for the researchers to filter the literature review on the foreign language issue such as in French, Spanish and Japanese language. To analyse systematically, seven literature review has been identified as the essential indicator in producing the space and gap on the research of "German language syntax" and "interferences" for the German language. 
Table 1: The Literature Review On The Topic Of German Language Syntax And

Interferences

\begin{tabular}{|c|c|c|c|c|c|}
\hline $\begin{array}{l}\text { Numbers } \\
\text { /Researchers }\end{array}$ & $\begin{array}{l}\text { Research } \\
\text { titles }\end{array}$ & \begin{tabular}{l}
\multicolumn{2}{l}{ Background } \\
of the \\
research
\end{tabular} & Issues/Gap & $\begin{array}{l}\text { Methodolog } \\
\text { y }\end{array}$ & $\begin{array}{l}\text { Findings of } \\
\text { studies }\end{array}$ \\
\hline $\begin{array}{l}\text { 1.Haslina } \\
\text { Daud, } 2016\end{array}$ & $\begin{array}{l}\text { The } \\
\text { construction } \\
\text { of sentences } \\
\text { in the German } \\
\text { language } \\
\text { among } \\
\text { Malay's } \\
\text { students in } \\
\text { UiTM Shah } \\
\text { Alam. }\end{array}$ & $\begin{array}{l}\text { This research is } \\
\text { meant to } \\
\text { identify the } \\
\text { German } \\
\text { language } \\
\text { pattern of } \\
\text { sentences by } \\
\text { the Malay } \\
\text { respondents } \\
\text { and identify } \\
\text { which of the } \\
\text { sentence } \\
\text { structure in } \\
\text { German that } \\
\text { causing } \\
\text { difficulty to the } \\
\text { respondents. } \\
\text { Respondents } \\
\text { are the students } \\
\text { from UiTM } \\
\text { Shah Alam, } \\
\text { Malay's and } \\
\text { can speak first } \\
\text { and second } \\
\text { language } \\
\text { fairly. }\end{array}$ & $\begin{array}{l}\text { This } \\
\text { research is } \\
\text { trying to } \\
\text { identify the } \\
\text { L1 or L2 } \\
\text { that cause } \\
\text { the } \\
\text { difficulty or } \\
\text { influencing } \\
\text { the } \\
\text { respondents } \\
\text { however } \\
\text { there are no } \\
\text { lists of } \\
\text { interference } \\
\text { by the } \\
\text { respondents } \\
\text {. }\end{array}$ & $\begin{array}{l}\text { Using the } \\
\text { qualitative } \\
\text { methods by } \\
\text { pointing out a } \\
\text { set of } \\
\text { questions that } \\
\text { are used to } \\
\text { tests the skills } \\
\text { of the } \\
\text { respondents } \\
\text { in the German } \\
\text { language. }\end{array}$ & $\begin{array}{l}\text { The } \\
\text { researcher } \\
\text { found that the } \\
\text { L1 is less } \\
\text { influence by } \\
\text { the } \\
\text { construction } \\
\text { of sentences } \\
\text { in German } \\
\text { language but } \\
\text { L2 which is } \\
\text { the English } \\
\text { language is } \\
\text { influencing } \\
\text { the in in } \\
\text { respondents } \\
\text { greatly in } \\
\text { constructing } \\
\text { the sentences } \\
\text { in the } \\
\text { German } \\
\text { language. } \\
\text { This } \\
\text { because the } \\
\text { German language is in } \\
\text { the cluster or } \\
\text { Germanic } \\
\text { which is } \\
\text { together with } \\
\text { the English } \\
\text { language. } \\
\text { Hence, the } \\
\text { mother } \\
\text { tongue } \\
\text { language is } \\
\text { less influence } \\
\text { by therman } \\
\text { construction } \\
\text { sentences of } \\
\text { the Germage. } \\
\text { languaage }\end{array}$ \\
\hline $\begin{array}{l}\text { 2.Agus } \\
\text { Syahid\& }\end{array}$ & $\begin{array}{l}\text { Syntax } \\
\text { interference }\end{array}$ & $\begin{array}{l}\text { This research } \\
\text { or about the }\end{array}$ & $\begin{array}{l}\text { This } \\
\text { research }\end{array}$ & $\begin{array}{l}\text { The } \\
\text { methodology }\end{array}$ & $\begin{array}{l}\text { The findings } \\
\text { of the studies }\end{array}$ \\
\hline
\end{tabular}




\begin{tabular}{|c|c|c|c|c|c|}
\hline Muhammad & of Indonesian & interferences & finds & used in this & indicate that \\
\hline $\begin{array}{l}\text { Zaki Pahrul } \\
\text { Hadi, } 2018\end{array}$ & $\begin{array}{l}\text { language } \\
\text { among } \\
\text { German } \\
\text { language } \\
\text { students from } \\
\text { STIBA } \\
\text { Bumigora } \\
\text { Mataram } \\
\text { Angkatan } \\
2015\end{array}$ & $\begin{array}{l}\text { or the } \\
\text { symptoms of } \\
\text { error in } \\
\text { language. The } \\
\text { interference } \\
\text { can happen to } \\
\text { someone that is } \\
\text { studying the } \\
\text { foreign } \\
\text { language } \\
\text { which happens } \\
\text { to the students } \\
\text { of STIBA } \\
\text { Bumigora the } \\
\text { cluster of } \\
\text { students in the } \\
\text { year 2015. } \\
\text { These students } \\
\text { are learning the } \\
\text { German } \\
\text { language as the } \\
\text { second language and } \\
\text { the researchers } \\
\text { took their } \\
\text { composition to } \\
\text { see their } \\
\text { construction of } \\
\text { sentences. }\end{array}$ & $\begin{array}{l}\text { the } \\
\text { interference } \\
\text { s which } \\
\text { include } \\
\text { phonology } \\
\text { interference } \\
\text { s, lexical } \\
\text { morphologi } \\
\text { sts, } \\
\text { and syntax } \\
\text { interference } \\
\text { s. The focus } \\
\text { on syntax } \\
\text { interference } \\
\text { s is } \\
\text { including } \\
\text { two types of } \\
\text { interference } \\
\text { which inter- } \\
\text { language } \\
\text { interference } \\
\text { and intra- } \\
\text { language } \\
\text { interference } \\
\text { and focused } \\
\text { on the } \\
\text { analysis of } \\
\text { errors and } \\
\text { involving } \\
\text { the la } \\
\text { Indonesian } \\
\text { language as } \\
\text { the L1. }\end{array}$ & $\begin{array}{l}\text { research } \\
\text { is } \\
\text { descriptive } \\
\text { analysis. }\end{array}$ & $\begin{array}{l}\text { there is the } \\
\text { influence of } \\
\text { the } \\
\text { Indonesian } \\
\text { language as } \\
\text { the } \\
\text { interlanguage } \\
\text { interference } \\
\text { in the } \\
\text { structures of } \\
\text { the sentence } \\
\text { in the } \\
\text { German } \\
\text { language. } \\
\text { Among them } \\
\text { are the } \\
\text { mistakes in } \\
\text { words } \\
\text { placement } \\
\text { and removal } \\
\text { of auxiliary } \\
\text { verbs. Next, } \\
\text { the mistakes } \\
\text { caused by } \\
\text { intra- } \\
\text { language } \\
\text { interference } \\
\text { are the } \\
\text { mistakes that } \\
\text { happen due to } \\
\text { the lack of } \\
\text { understandin } \\
\text { g of } \\
\text { respondents } \\
\text { towards the } \\
\text { German } \\
\text { language } \\
\text { method. }\end{array}$ \\
\hline $\begin{array}{l}\text { 3.Obodoeze } \\
\text { Nkechi } \\
\text { Juliette \& } \\
\text { Ugagu- } \\
\text { Dominic } \\
\text { Nneka } \\
\text { Rachael, } \\
2018\end{array}$ & $\begin{array}{l}\text { Interference } \\
\text { in Foreign } \\
\text { Language } \\
\text { Learning: } \\
\text { The Example } \\
\text { of Nigerian } \\
\text { German } \\
\text { Learners }\end{array}$ & $\begin{array}{l}\text { The research } \\
\text { on the German } \\
\text { language } \\
\text { students in } \\
\text { Nigeria and the } \\
\text { influence of L1 } \\
\text { and L2 towards } \\
\text { the German } \\
\text { language. The } \\
\text { researchers are } \\
\text { looking at the }\end{array}$ & $\begin{array}{l}\text { The } \\
\text { researchers } \\
\text { are } \\
\text { explaining } \\
\text { the } \\
\text { influence of } \\
\text { the English } \\
\text { language } \\
\text { which is } \\
\text { considered } \\
\text { as lingua }\end{array}$ & $\begin{array}{l}\text { The } \\
\text { researchers } \\
\text { are not } \\
\text { explaining in } \\
\text { detail the } \\
\text { methodology } \\
\text { and the data } \\
\text { collection } \\
\text { method from } \\
\text { the students } \\
\text { however the }\end{array}$ & $\begin{array}{l}\text { The findings } \\
\text { of the studies } \\
\text { indicate that } \\
\text { the } \\
\text { multicultural } \\
\text { and variety of } \\
\text { languages } \\
\text { known by the } \\
\text { students can } \\
\text { be a } \\
\text { distraction in }\end{array}$ \\
\hline
\end{tabular}




\begin{tabular}{|c|c|c|c|c|c|}
\hline & & $\begin{array}{l}\text { mistakes of } \\
\text { sentences } \\
\text { construction by } \\
\text { the students in } \\
\text { Nigeria. }\end{array}$ & $\begin{array}{l}\text { franca in } \\
\text { Nigeria and } \\
\text { influencing } \\
\text { the dialects } \\
\text { in Nigerian } \\
\text { language } \\
\text { which will } \\
\text { influence } \\
\text { the } \\
\text { student's } \\
\text { developmen } \\
\text { t. }\end{array}$ & $\begin{array}{l}\text { researchers } \\
\text { explain that } \\
\text { the sentences } \\
\text { constructed } \\
\text { by the } \\
\text { students } \\
\text { contain the } \\
\text { syntax error } \\
\text { in the German } \\
\text { language. }\end{array}$ & $\begin{array}{l}\text { learning the } \\
\text { German } \\
\text { language. }\end{array}$ \\
\hline $\begin{array}{l}\text { 4.Wan Lin } \\
\text { Tsai, } 2015\end{array}$ & $\begin{array}{l}\text { English } \\
\text { Interferences } \\
\text { in German } \\
\text { Sentences }\end{array}$ & $\begin{array}{l}\text { This research is } \\
\text { about the } \\
\text { university } \\
\text { students in } \\
\text { Taiwan that } \\
\text { learning } \\
\text { German } \\
\text { language and } \\
\text { find that the } \\
\text { Chinese } \\
\text { language } \\
\text { distracting } \\
\text { them } \\
\text { constructing in } \\
\text { the sentences } \\
\text { in the German } \\
\text { language. }\end{array}$ & $\begin{array}{l}\text { The } \\
\text { researchers } \\
\text { explain the } \\
\text { German } \\
\text { language } \\
\text { which is the } \\
\text { third } \\
\text { language in } \\
\text { Taiwan. The } \\
\text { second } \\
\text { language } \\
\text { which is the } \\
\text { Chinese } \\
\text { language is } \\
\text { distracting } \\
\text { the } \\
\text { construction } \\
\text { of sentences } \\
\text { in the } \\
\text { German } \\
\text { language. } \\
\text { Therefore, } \\
\text { the Chinese } \\
\text { and English } \\
\text { language } \\
\text { are causing } \\
\text { the students } \\
\text { to tend to } \\
\text { make } \\
\text { mistakes in } \\
\text { constructing } \\
\text { the } \\
\text { sentences. }\end{array}$ & $\begin{array}{l}\text { The } \\
\text { researchers } \\
\text { are using the } \\
\text { qualitative } \\
\text { method and } \\
\text { forming the } \\
\text { research } \\
\text { hypothesis } \\
\text { which is } \\
\text { namely as } \\
\text { "Contrastive } \\
\text { Analysis } \\
\text { Hypothesis } \\
\text { (CAH)". }\end{array}$ & $\begin{array}{l}\text { The } \\
\text { researches are } \\
\text { not producing } \\
\text { statistics on } \\
\text { the number of } \\
\text { language } \\
\text { distractions } \\
\text { however find } \\
\text { that there are } \\
\text { two important } \\
\text { elements in } \\
\text { the research. } \\
\text { The } \\
\text { distraction of } \\
\text { English and } \\
\text { Chinese } \\
\text { language and } \\
\text { divided it into } \\
\text { five types of } \\
\text { error in } \\
\text { constructing } \\
\text { sentences } \\
\text { which are } \\
\text { gender article } \\
\text { sentence } \\
\text { arrangement, } \\
\text { pronouns, } \\
\text { adjectives, } \\
\text { verbs, } \\
\text { articles, and } \\
\text { tenses. }\end{array}$ \\
\hline $\begin{array}{l}\text { 5.Wan Ting } \\
\text { Tan \& Nicole } \\
\text { Ogasa, } 2015\end{array}$ & $\begin{array}{l}\text { Mandarin } \\
\text { Chinese and } \\
\text { English } \\
\text { Transfer } \\
\text { during } \\
\end{array}$ & $\begin{array}{l}\text { The research } \\
\text { about the } \\
\text { Mandarin } \\
\text { language } \\
\text { speaker among }\end{array}$ & $\begin{array}{l}\text { The } \\
\text { researchers } \\
\text { are looking } \\
\text { up to how } \\
\text { the research }\end{array}$ & $\begin{array}{l}\text { The } \\
\text { researchers } \\
\text { are using the } \\
\text { qualitative } \\
\text { method as an }\end{array}$ & $\begin{array}{l}\text { The findings } \\
\text { of the studies } \\
\text { show that the } \\
\text { noun that } \\
\text { contains the }\end{array}$ \\
\hline
\end{tabular}




\begin{tabular}{|c|c|c|c|c|c|}
\hline & $\begin{array}{l}\text { German } \\
\text { Language } \\
\text { Acquisition } \\
\text { Examples of } \\
\text { Structural } \\
\text { Properties } \\
\text { Transfer }\end{array}$ & $\begin{array}{l}\text { the students in } \\
\text { Malaysian } \\
\text { Universities. }\end{array}$ & $\begin{array}{l}\text { participants } \\
\text { shift the } \\
\text { Mandarin } \\
\text { language to } \\
\text { the English } \\
\text { language } \\
\text { and } \\
\text { constructing } \\
\text { the } \\
\text { sentences in } \\
\text { the German } \\
\text { language. }\end{array}$ & $\begin{array}{l}\text { approach for } \\
\text { this case } \\
\text { study which } \\
\text { involves } 17 \\
\text { German } \\
\text { language } \\
\text { students that } \\
\text { came from } \\
\text { the Chinese } \\
\text { race and } \\
\text { known to the } \\
\text { Mandarin } \\
\text { language. }\end{array}$ & $\begin{array}{l}\text { specifics of } \\
\text { German } \\
\text { articles such } \\
\text { as "the" and } \\
\text { "a" in the } \\
\text { English } \\
\text { language. } \\
\text { The } \\
\text { researchers } \\
\text { found that the } \\
\text { participants } \\
\text { are confused } \\
\text { because the } \\
\text { German } \\
\text { language } \\
\text { needs to be } \\
\text { explained } \\
\text { with gender. }\end{array}$ \\
\hline $\begin{array}{l}\text { 6.Anne } \\
\text { Baker, } 2017\end{array}$ & $\begin{array}{l}\text { Error } \\
\text { Analysis and } \\
\text { Language } \\
\text { Comparison } \\
\text { as Teaching } \\
\text { Strategies for } \\
\text { German as a } \\
\text { Foreign } \\
\text { Language in a } \\
\text { South African } \\
\text { Context. }\end{array}$ & $\begin{array}{l}\text { The research is } \\
\text { about the } \\
\text { school students } \\
\text { in South Africa } \\
\text { that learned the } \\
\text { German } \\
\text { language as } \\
\text { targeted } \\
\text { language. The } \\
\text { school students } \\
\text { are the research } \\
\text { participants } \\
\text { and spoke the } \\
\text { African } \\
\text { language, } \\
\text { Bantu and Zulu } \\
\text { (Multilingual). }\end{array}$ & $\begin{array}{l}\text { The main } \\
\text { focus of the } \\
\text { research is } \\
\text { on the } \\
\text { school } \\
\text { student's } \\
\text { sentence } \\
\text { construction } \\
\text { and the } \\
\text { students that } \\
\text { learning the } \\
\text { German } \\
\text { language } \\
\text { that shows } \\
\text { their } \\
\text { mistakes in } \\
\text { sentences } \\
\text { due to using } \\
\text { the } \\
\text { language } \\
\text { that they } \\
\text { mastered as } \\
\text { the strategy } \\
\text { to construct } \\
\text { the German } \\
\text { language } \\
\text { sentence. }\end{array}$ & $\begin{array}{l}\text { This research } \\
\text { has been done } \\
\text { analysed on } \\
\text { the content of } \\
\text { the sentences } \\
\text { in the } \\
\text { student's } \\
\text { composition. } \\
\text { The results } \\
\text { are depicted } \\
\text { in the form of } \\
\text { a percentage. }\end{array}$ & $\begin{array}{l}\text { The findings } \\
\text { of studies } \\
\text { indicate that } \\
\text { the strategy } \\
\text { of adapting } \\
\text { the known } \\
\text { language by } \\
\text { the research } \\
\text { participants } \\
\text { causes them } \\
\text { to make } \\
\text { mistakes in } \\
\text { constructing } \\
\text { the sentences } \\
\text { in the } \\
\text { German } \\
\text { language. }\end{array}$ \\
\hline $\begin{array}{l}\text { 7.Robe'ah } \\
\text { Yusuf, } \\
\text { Khairul Bahri } \\
\text { Abdul } \\
\text { Samad, }\end{array}$ & $\begin{array}{l}\text { Instrument } \\
\text { Construction } \\
\text { for Analyzing } \\
\text { Errors of } \\
\text { German }\end{array}$ & $\begin{array}{l}\text { Discussion } \\
\text { about the } \\
\text { research } \\
\text { instrument for }\end{array}$ & $\begin{array}{l}\text { The } \\
\text { research is } \\
\text { limited } \\
\text { because } \\
\text { there is no }\end{array}$ & $\begin{array}{l}\text { This research } \\
\text { is meant to } \\
\text { explain the } \\
\text { methodology } \\
\text { and types of }\end{array}$ & $\begin{array}{l}\text { The } \\
\text { discussion is } \\
\text { explaining } \\
\text { the types of } \\
\text { questions and }\end{array}$ \\
\hline
\end{tabular}




\begin{tabular}{|c|c|c|c|c|c|}
\hline $\begin{array}{l}\text { Norjietta@Ju } \\
\text { lita Taisin \& } \\
\text { Zarima Mohd } \\
\text { Zakaria, } 2019\end{array}$ & $\begin{array}{l}\text { Language } \\
\text { Writing by } \\
\text { The Students } \\
\text { of Universiti } \\
\text { Pendidikan } \\
\text { Sultan Idris }\end{array}$ & $\begin{array}{l}\text { syntax research } \\
\text { at UPSI. }\end{array}$ & $\begin{array}{l}\text { finding of } \\
\text { the studies } \\
\text { and only } \\
\text { discussing } \\
\text { the } \\
\text { developmen } \\
t \text { of items } \\
\text { and } \\
\text { questions to } \\
\text { the research } \\
\text { participants. }\end{array}$ & $\begin{array}{l}\text { questionnaire } \\
\mathrm{s} \text { constructed } \\
\text { and to be } \\
\text { processed and } \\
\text { delivered to } \\
\text { the experts } \\
\text { for } \\
\text { validation. }\end{array}$ & $\begin{array}{l}\text { items that } \\
\text { involve the } \\
\text { construction } \\
\text { of sentences } \\
\text { in the } \\
\text { German } \\
\text { language } \\
\text { which are the } \\
\text { interrogative, } \\
\text { sentence } \\
\text { arrangement } \\
\text { and } \\
\text { constructing } \\
\text { sentences } \\
\text { through the } \\
\text { words given. }\end{array}$ \\
\hline
\end{tabular}

Referred to Table 1. on the literature review that has been done, there are only seven latest researches and studies that are related to the "German language syntax" and "Interferences". Three articles mentioned clearly that the English language is the reference to the construction of sentences in the German language due to the similarity of typology. (Haslina, 2016). Based on the literature review, it clearly shows that there is still lacking studies about constructing sentences in the German language. Almost all of the researchers found and suggest that the first language will influence the construction of sentences in the German language. However, Obodoeze and Ugagu-Dominic (2018), suggest that the English language is simpler to be referred by the research participant because they have mastered the language. English and German language are quite similar because they are in the same group in Germanic. Having vast knowledge in languages as a native in Africa also causing the research participants to make their first language as interference (Baker, 2017). It is found that the German language researcher in various fields of linguistics is from Indonesia. The researcher from Malaysia mostly tends to study German grammar. While the researcher from Africa mostly discussed the difficulty of the participants in learning the German language because Africans are multilingual (Baker, 2017). The researcher about Mandarin speakers as the first language found that the structure of sentences by the participants is referring to the Chinese or Mandarin language sentence structure. (Wan Lin, 2015; Wan Ting \&Ogasa, 2015). The difficulty of obtaining the articles about German language syntax that specifically on language interference is showing the gaps in this area of study.

\section{Conclusion}

The utilization of methodology in surveying the literature review explains some issues in German language syntax. The issues are the influence of first and second language in constructing sentences and sentence construction structures. It is found that most of all the researchers are studies on syntax error to find the mistakes that happen during constructing a sentence in to correct. Some researchers make a comparison of the sentence structure with the mother tongue language. However, this study is certainly not enough to explain "German language syntax" with the pattern of sentence construction. Other than that, there is still the least of researchers that making classification of referred language "interferences" from the study participants. Most of the researchers are making classification on the German language grammatical error. Thus, this study is important to be implemented because it will fill the void 
and helping the people involve in teaching and learning of German language whether in school or universities. The least of references can result in the difficulty for other researchers to gain better insights into the German language.

\section{Acknowledgment}

This article was based on the research project "Geran Galakan Penyelidikan Universiti”, Code: GGPU 2018-0070-107-01, funded by Research Management Innovation Centre (RMIC), Sultan Idris Education University.

\section{References}

Agus Syahid \& Muhammad Zaki Pahrul Hadi, (2018), Interferensi sintaksis bahasa Indonesia dalam karangan bahasa Jerman mahasiswa/i Stiba Bumigora Mataram angkatan 2015. Journal of Languages and Language Teaching, vol.6 no.2.68-76.

Aida Husni Abdul Hamid. (2012). Analisis Penggunaan Kata Kerja Bahasa Jerman dalam Kalangan Pelajar IPTA. Kuala Lumpur: Universiti Malaya.

Baker, A. (2017). Error analysis and language comparison as teaching strategies for German as a foreign language in a South African context. Problemy wczesnej edukacji / Issues in Early Education 2 (37).103-110.

Baumeister, R. F., \& Leary, M. R. (1997). Writing narrative literature reviews. Review of general psychology, 1(3).311-320.

Bem, D. J. (1995). Writing a review article for Psychological Bulletin. Psychological Bulletin, 118.172-177.

Cooper, H. M. (2003). Editorial. Psychological Bulletin, 129. 3-9.

Dewey, A. \& Drahota, A. (2016) Introduction to systematic reviews: online learning module Cochrane Training https://training.cochrane.org/interactivelearning/module-1introduction-conducting-systematic-reviews

Haslina Daud. (2016). Pembinaan Ayat Bahasa Jerman Dalam Kalangan Pelajar-pelajar Melayu di UiTM Shah Alam. Master thesis, University of Malaya.

Kaiser, I., Peyer, E., \& Berthele, R. (2014). Does different mean difficult? Contrastivity and foreign language reading: Some data on reading in German. International Journal of Bilingualism, 18(3). 222-243.

Maslida Yusof (2006). Struktur Leksikal dalam Sintaksis dan Semantik: Kajian Terhadap Kata Kerja dan Preposisi Bahasa Melayu. Tesis PHD. Bangi: Universiti Kebangsaan Malaysia.

Michie, S., \& Williams, S. (2003). Reducing work-related psychological ill health and sickness absence: a systematic literature review. Occupational and environmental medicine, 60(1). 3-9.

Obodoeze, Nkechi \& Nneka, Ugagu-Dominic. (2018). Intererference in foreign language learning: The example of Nigerian German learners. International Journal of Arts, Languages, Linguistics and Literary Studies, 2, 99-111.

Robe'ah Yusuf, Khairul Bahri Abd Samad, Norjietta Julita Taisin, \& Zarima Mohd Zakaria (2019). Instrument Construction for Analyzing Errors of German Language Writing by the Students of Universiti Pendidikan Sultan Idris. Prosiding Seminar Internasional prosiding Dalam Rangka Kegiatan Studi Visit 2019. 59-68.

Robe'ah Yusuf. (2010). Analisis kesilapan dalam konjugasi kata kerja regular dan irregular bahasa Jerman dalam kalangan pelajar Universiti Pendidikan Sultan Idris. Geran Penyelidikan Universiti.

Rowinah Jakiwa. (2012). Gaya Pembelajaran Pelajar Diploma dalam Mempelajari Bahasa Jerman. Kuala Lumpur: Universiti Malaya. 
Tan, Wan Ting and Ogasa, Nicole. (2015). Mandarin Chinese and English transfer during German language acquisition examples of structural properties transfer. International Journal of Liberal Arts and Social Science, 3 (5), 95-106.

Wan, L.T, (2015). English interferences in German sentence. Linguistics and Literature Studies 3(6), 278-283. http://www.hrpub.org DOI: 10.13189/1ls.2015.030604 